\title{
The Effectiveness of Acupressure Therapy on Decreasing Complaints of Nausea and Vomiting in Pregnant Women
}

\section{Dita Indah Sari ${ }^{*}$, Sri Wahyuningsih²}

1Prodi D3 Keperawatan Fakultas Keperawatan Universitas Jember, Indonesia; ditaindah567@gmail.com (Corresponding Author) 2Prodi D3 Keperawatan Fakultas Keperawatan Universitas Jember, Indonesia

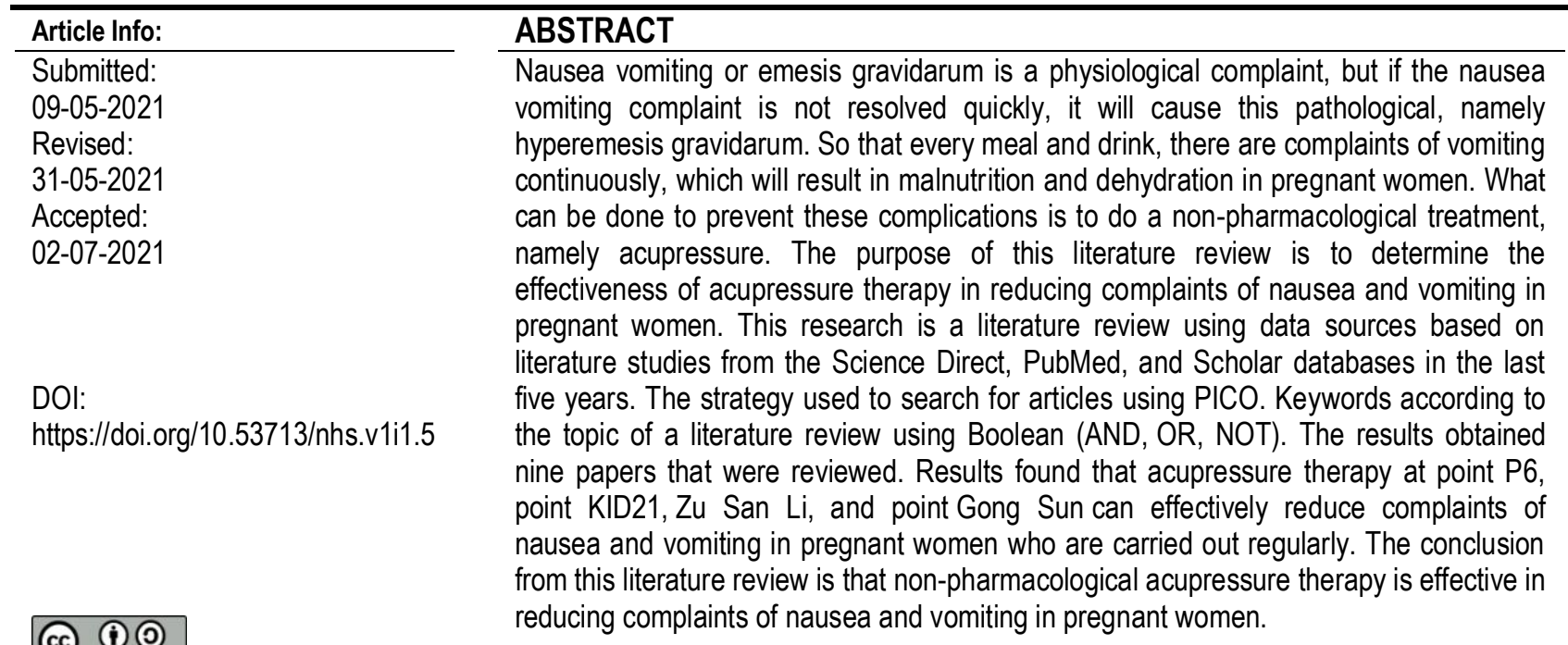

This work is licensed under CC BY-SA License.
Keywords: acupressure; nausea and vomiting; emesis gravidarum; pregnant women; gestational

\section{INTRODUCTION}

Pregnancy is a natural event that will occur by a woman. When a woman is pregnant, there will be many changes in her body. One of them is physiological changes such as nausea, vomiting, back pain and frequent urination (Suryaningrum, Titisari, \& Mediawati, 2018). The most common complaint felt by pregnant women in the early trimester is nausea and vomiting. The term that describes this state of nausea and vomiting is called emesis gravidarum or morning sickness, even though these complaints arise at any time, not just in the morning (Fatwa Tasya T, 2020). Morning sickness or nausea and vomiting is a condition in pregnant women that occurs at the 6th week of pregnancy and ends in the 11th week to the 16th week (Wahyuningsih S, 2019). Meanwhile, according to Ramadhani and Ayudia, (2019) morning sickness or nausea and vomiting starts at the $4^{\text {th }}$ week ending in the $14^{\text {th }}$ to $16^{\text {th }}$ week of pregnancy.

Nausea vomiting or emesis gravidarum is a physiological complaint, but if the nausea and vomiting complaint is not resolved quickly, it will cause pathological problems because it can result in reduced fluid in the body and will result in hemo-concentration and later blood circulation will slow down so that it can affect development and growth in the fetus (Wulandari, Kustriyanti, \& Aisyah, 2019). In addition, pregnant women who are facing emesis gravidarum, if left untreated, can cause hyperemesis gravidarum so that every meal and drink complaints of vomiting continuously occur (Henuk \& Pattypeilohy, 2019).

Nausea and vomiting in pregnant women rarely cause death, but the incidence is still quite high. According to the World Health Organization, (2014) the incidence of emesis gravidarum in pregnancy reaches $12.5 \%$ in the world. Meanwhile, the incidence of emesis gravidarum in Indonesia is $50-90 \%$ experienced by pregnant women (Faridah, Ponda, \& Pertiwi, 2020). Based on the 2015 Ministry of Health in East Java, the incidence of pregnant women with emesis gravidarum was $10 \%-15 \%$ of the 182,815 number of pregnant women in 2015 . The incidence of hyperemesis gravidarum around the world varies widely, in Indonesia, namely 1.5 - 3\% of the total pregnant women in Indonesia (Faridah et al., 2020). Meanwhile, based on the Indonesian Ministry of Health in 2018, the incidence of mothers with hyperemesis gravidarum in Indonesia reached $14.8 \%$ of all pregnancies. 
Nausea and vomiting during pregnancy are caused by increased levels of the hormones estrogen and progesterone produced by Chronionic Gonadotropin (HCG) in the placenta (Soa, Amelia, \& Octaviani, 2018). Pregnant women who experience complaints of nausea and vomiting are a natural symptom that will be felt in the first trimester, usually the mother will experience signs of symptoms such as dizziness, excessive salivation, and partially expelling food and even everything that has been consumed. In addition, there are many cases of pregnant women experiencing excessive nausea and vomiting that can worsen the general condition of the mother and can interfere with the daily activities of pregnant women. Nausea and vomiting in pregnancy can have serious repercussions on the mother and especially on the fetus. Low Birth Weight (LBW) and preterm birth are the most common consequences that can harm the fetus due to the severity of nausea and vomiting experienced by the mother (Sulistiarini, Widyawati, \& Rahayu, 2018).

Pregnant women are required to be able to adapt to complaints of nausea and vomiting, if they cannot adapt it can cause harm to both the pregnant mother and the fetus in her womb. Pregnant women who experience nausea and vomiting really need adequate nutrition. If the nutritional intake is reduced, the weight of pregnant women will decrease, which can also have a negative impact on the fetus they are carrying (WS Dewi \& Safitri, 2018). Pregnant women will experience complications if nausea and vomiting are not resolved. Malnutrition and dehydration are the most obvious complications. If pregnant women cannot handle it properly, it can result in loss of fluid in the stomach resulting in dehydration, hypokalemia, and metabolic alkalosis (Maheswara, Wahyuni, Istiqomah, \& Kustiyati, 2020).

What can be done to prevent these complications is to do a management. Various preventive measures are taken by health workers for pregnant women who are experiencing nausea and vomiting so that the condition does not become more severe by changing the lifestyle of adequate rest and avoiding stress, and not consuming carbonated drinks and adjusting the diet a little but often (Dhilon \& Azni, 2018). Treatment of pregnant women to treat nausea and vomiting is carried out by means of pharmacological treatment and non-pharmacological treatment. Antihistamines, antimietics, and corticosteroids are pharmacological therapies that can be given to pregnant women when experiencing nausea and vomiting (Sulistiarini et al., 2018). Meanwhile, non-pharmacological therapy for complaints of nausea and vomiting of pregnant women is carried out by adjusting diet, emotional support, acupressure and ginger (Runiari, 2010) in (Sulistiarini et al., 2018).

This non-pharmacological treatment with the acupressure method is a method that is safe for pregnant women and their fetuses. This acupressure technique is a development of massage therapy, and is closely related to the development of acupuncture, because acupressure techniques originate from acupuncture. Acupressure therapy is carried out using fingers to replace needles, but it is still carried out at the same point in acupuncture therapy (Hartono, 2012) in (Renityas, 2019).

It has been proven in the research of Widyastuti et al. (2019) that after acupressure therapy intervention was carried out on pregnant women who were facing nausea and vomiting, the calculation of nausea and vomiting scores was $0.005<0.05$, there was a comparison between the results of the post-test and pre-test, which meant that the acupressure method was efficient. treat emesis gravidarum or nausea and vomiting in first trimester pregnant women. Likewise, in Mariza and Ayuningtias' research, (2019) the results obtained $p$-value $=0.000$, which means that there is an effect of acupressure at point P6 to overcome emesis gravidarum. This stimulatory effect on P6 can increase the release of betaendorphins in the pituitary and adrenocorticotropic (ACTH) along the CTZ which can block the vomiting center (Fengge, 2012) in deep (Tanjung, Wari, \& Antoni, 2020).

Based on the explanation above, it can be concluded that there are many links regarding acupressure therapy in reducing complaints of nausea and vomiting in pregnant women. Therefore, the authors conducted a literature review on the effectiveness of acupressure therapy in reducing complaints of nausea and vomiting in pregnant women.

\section{METHOD}

This study is a comprehensive summary in the form of a literature review on the effectiveness of acupressure therapy in reducing complaints of nausea and vomiting in pregnant women. The protocol and evaluation of the literature review will use the PRISMA checklist for the selection of studies found that are tailored to the purpose of the literature review. The method used is in the form of literature review, while the purpose of this study is to collect and analyze articles or journals related to acupressure therapy in pregnant women who experience complaints of nausea and vomiting. Literature search was carried out in January to February 2021. The data in this literature review used secondary data obtained from the results of previous research researchers from 2016 to 2021. Methods of data collection using electronic databases include Science Direct, PubMed, and Scholar. 
Searching for journals or articles in review literature this uses keywords (AND, OR, NOT) which are used to specify and expand the search, so that it will be easier to determine which articles or journals to use. Keywords tailored to the Medical Subject Headings consisting of the following:

Table 1. Keywords literature review

\begin{tabular}{ccc}
\hline Acupressure & Nausea and Vomiting & Pregnancy \\
\hline acupressure & Nausea and vomiting & Pregnant Women \\
\hline OR & OR & OR \\
\hline Pressure & Emesis Gravidarum & Gestational \\
\hline & OR & OR \\
\hline NVP & Pregnancy \\
\hline \multicolumn{3}{c}{ OR } \\
\hline
\end{tabular}

Strategy used to search articles using PICO, which consists of Population / problem, Intervention, Comparation, and Study design.

Table 2. Format PICO in the literature review

\begin{tabular}{lll}
\hline \multicolumn{1}{c}{ Criteria for } & \multicolumn{1}{c}{ Inclusion } & \multicolumn{1}{c}{ exclusion } \\
\hline Population & $\begin{array}{l}\text { Studies comprised affected Pregnant Women with } \\
\text { Nausea and vomiting, gestational age of }<20 \text { weeks, } \\
\text { maternal age between 18-40 years }\end{array}$ & $\begin{array}{l}\text { Pregnant women without nausea and vomiting, } \\
\text { gestational age of }>20 \text { weeks, maternal age not } \\
\text { between } 18-40 \text { years }\end{array}$ \\
\hline Intervention & Acupressure Therapy & No exclusion \\
\hline Comparators & Treatment with vitamin B6 and metoclopramide & No comparator \\
\hline Outcomes & Effect Acupressure Therapy on the nausea and vomiting & $\begin{array}{l}\text { Not described Effect Acupressure Therapy on the } \\
\text { nausea and vomiting }\end{array}$ \\
\hline $\begin{array}{l}\text { Study Design } \\
\text { and publication } \\
\text { Type }\end{array}$ & $\begin{array}{l}\text { Quasi-experimental studies, randomized control and trial, } \\
\text { qualitative research and cross-sectional studies }\end{array}$ & No exclusion \\
\hline $\begin{array}{l}\text { Publication } \\
\text { years }\end{array}$ & Post-2016 & Pre-2016 \\
\hline Language & English, Indonesian & Language other than English and Indonesian \\
\hline
\end{tabular}

The search strategy in this literature study uses a data base including Science Direct, PubMed, and Scholar through link to the National Library of the Republic of Indonesia and access from the University of Jember. In the initial search phase, there were 85 articles (ScienceDirect $=62$, PubMed $=11$, Scholar $=12$ ), after being filtered from 2016 to 2021. There were 43 articles that did not match the study area. Then the researchers selected 17 articles with titles and abstracts. Obtained 3 articles not full text. And 2 articles apart from using English and Indonesian. After that the articles obtained were examined based on duplication, there were 2 articles that were the same so they were excluded. The total number of articles that can be reviewed is 9 articles. The results of the selection of this article can be illustrated in the Diagram Flow below. 


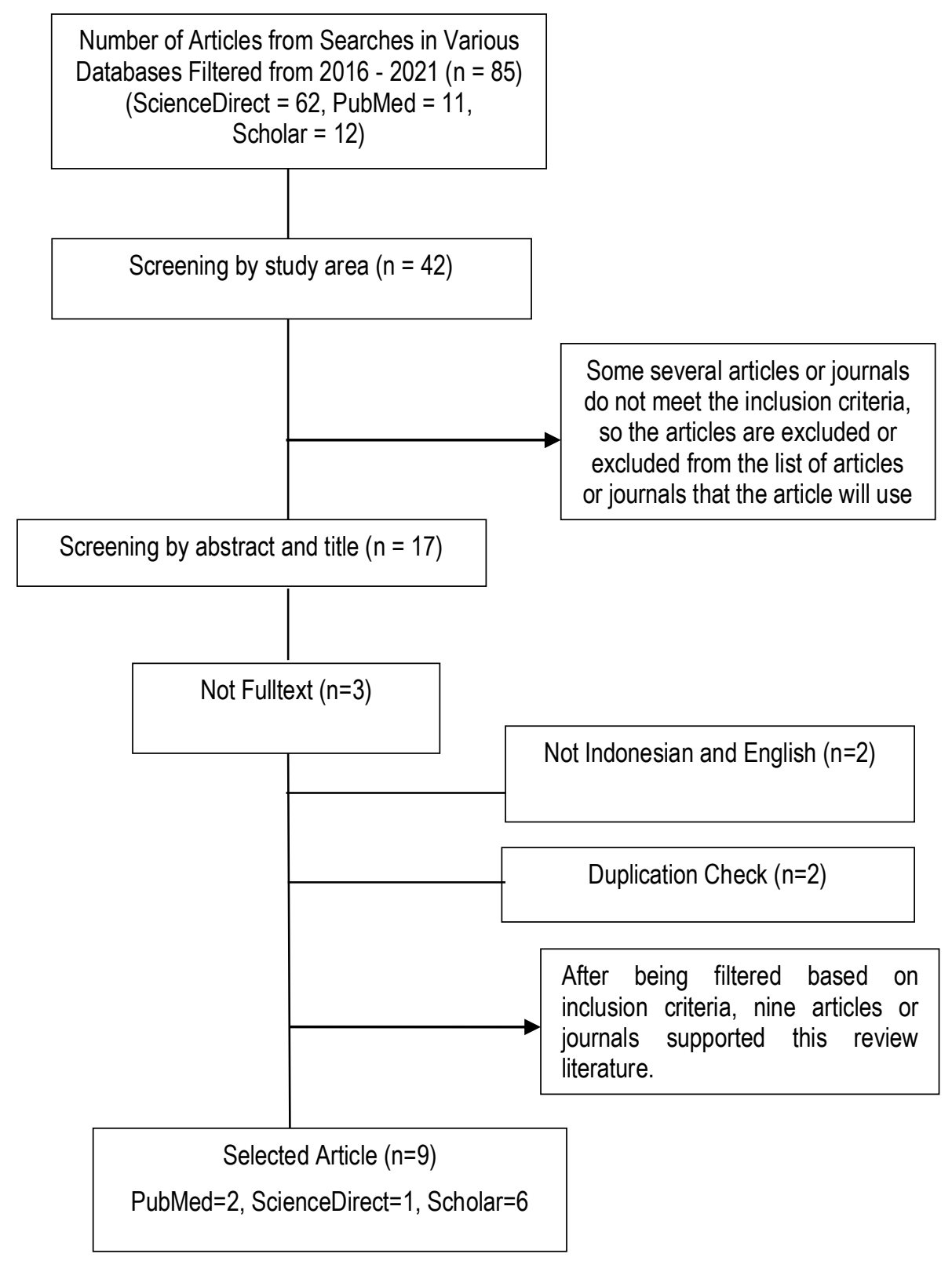

Figure 1. Diagram flow literature review

RESULT

Table 3. Characteristics of Study

\begin{tabular}{lll}
\hline 1. & Iran & $\begin{array}{l}\text { (Mobarakabadi, Shahbazzadegan, \& Ozgoli, 2020); (Galeshi, Ghanbarpour, Naeimi Rad, \& Asghari, 2020); } \\
\text { (Tara et al., 2020) }\end{array}$ \\
\hline 2. & India & (Devi, Lepcha, \& Das, 2020) \\
\hline 3. Indonesia & $\begin{array}{l}\text { (Tanjung et al., 2020); (RK Dewi \& Saidah, 2020); (Mariza \& Ayuningtias, 2019); (Meiri \& Kibas, 2018); } \\
\text { (Handayani \& Khairiyatul, 2019) }\end{array}$ \\
\hline
\end{tabular}

Respondents or participants in some of these studies, pregnant women aged 18-40 years experienced complaints of nausea and vomiting caused by physiological changes during pregnancy, with gestational age from 1 to 19 
weeks (first trimester to early second trimester) due to complaints of nausea. and vomiting in pregnant women is very prone to occur in the first trimester.

Table 4. Theoretical Mapping

\begin{tabular}{|c|c|c|c|c|c|}
\hline No. & Author & Title & $\begin{array}{l}\text { Design and } \\
\text { sample }\end{array}$ & Intervention & Results \\
\hline 1. & $\begin{array}{l}\text { (Mobarakabadi } \\
\text { et al., 2020) } \\
\text { Index: Q3 }\end{array}$ & $\begin{array}{l}\text { The effect of } P 6 \\
\text { acupressure on } \\
\text { nausea and } \\
\text { vomiting of } \\
\text { pregnancy }\end{array}$ & $\begin{array}{l}\text { A } \\
\text { randomized, } \\
\text { single-blind, } \\
\text { placebo- } \\
\text { controlled trial } \\
75 \text { pregnant } \\
\text { women, mild } \\
\text { to moderate } \\
\text { nausea and } \\
\text { vomiting, } \\
\text { gestational } \\
\text { age <20 } \\
\text { weeks. }\end{array}$ & $\begin{array}{l}\text { Pressed at P6 in the } \\
\text { acupressure group } \\
\text { for three days using } \\
\text { thebutton Sea-Band. } \\
\text { In the placebo } \\
\text { group, Sea-Band } \\
\text { was applied } \\
\text { unstressed at P6. } \\
\text { The control group } \\
\text { did not receive any } \\
\text { intervention, except } \\
\text { for dietary } \\
\text { recommendations } \\
\text { which were similar to } \\
\text { those of the other } \\
\text { two groups. The } \\
\text { frequency and } \\
\text { severity of nausea } \\
\text { and vomiting were } \\
\text { recorded for six } \\
\text { days, twice daily, } \\
\text { with intervention } \\
\text { starting on the fourth } \\
\text { day. }\end{array}$ & $\begin{array}{l}\text { There was a significant reduction in the } \\
\text { frequency, duration and severity of nausea as } \\
\text { well as the frequency of vomiting in the } \\
\text { acupressure and placebo groups but not in } \\
\text { the control group after three days of } \\
\text { intervention. Acupressure on P6 that is } \\
\text { applied using a wristband can reduce the } \\
\text { frequency and severity of nausea and } \\
\text { vomiting. And this is a safe method. } \\
\text { Dol: } \\
\text { https://doi.org/10.1016/i.aimed.2019.07.002 }\end{array}$ \\
\hline 2. & $\begin{array}{l}\text { (Tara et al., } \\
\text { 2020) } \\
\text { Pubmed } \\
\text { Index: Q2 }\end{array}$ & $\begin{array}{l}\text { The Effect of } \\
\text { Acupressure on } \\
\text { the Severity of } \\
\text { Nausea, } \\
\text { Vomiting, and } \\
\text { Retching in } \\
\text { Pregnant } \\
\text { Women }\end{array}$ & $\begin{array}{l}\text { Randomized } \\
\text { Controlled } \\
\text { Trial } \\
90 \quad \text { women } \\
\text { with singleton } \\
\text { pregnancies, } \\
\text { gestational } \\
\text { age below } 12 \\
\text { weeks. }\end{array}$ & $\begin{array}{l}\text { Patients were } \\
\text { randomly divided } \\
\text { into three groups: } \\
\text { 1. PC6 pressure } \\
\text { (4 times a day } \\
\text { in the morning } \\
\text { after waking, } \\
\text { noon, evening } \\
\text { and night } \\
\text { before going to } \\
\text { bed, for } 10 \\
\text { minutes with } \\
\text { constant } \\
\text { pressure } \\
\text { instead of with } \\
\text { massage). } \\
\text { Fake ice } \\
\text { acupressure } \\
\text { (pressure in } \\
\text { waiguan), and } \\
\text { 3. treatment with } \\
\text { vitamin B6 and } \\
\text { metoclopramid. } \\
\text { Assessment of the } \\
\text { severity of nausea, } \\
\text { vomiting and } \\
\text { vomiting was carried } \\
\text { out based on the } \\
\text { Rhodes Index on the }\end{array}$ & $\begin{array}{l}\text { The three groups differed significantly on day } \\
\text { five in terms of frequency of vomiting, distress } \\
\text { due to vomiting, duration of nausea, distress } \\
\text { due to nausea, amount of vomiting, frequency } \\
\text { of nausea, and frequency of vomiting ( } p \\
<0.001 \text { for each outcome). } \\
\text { DOI: https://doi.org/10.1159/000505637 }\end{array}$ \\
\hline
\end{tabular}


first and fifth days

(before and after the

intervention).

\begin{tabular}{|c|c|c|c|c|c|}
\hline 3. & $\begin{array}{l}\text { (Handayani \& } \\
\text { Khairiyatul, } \\
\text { 2019) } \\
\text { Index: S3 }\end{array}$ & $\begin{array}{l}\text { Effect } \\
\text { Acupressure of } \\
\text { Decreasing } \\
\text { Nausea and } \\
\text { Vomiting in } \\
\text { Pregnant } \\
\text { Women in } \\
\text { Sidoarjo Midwife } \\
\text { Independent } \\
\text { Practice }\end{array}$ & $\begin{array}{l}\text { Quasy- } \\
\text { Experiment } \\
22 \text { pregnant } \\
\text { women, } \\
\text { trimester } 1 \text { - } 2 \\
\text { The }\end{array}$ & $\begin{array}{l}\text { intervention group } \\
\text { was given } \\
\text { acupressure } \\
\text { treatment at the } \\
\text { pericardium point } 6 \text {, } \\
\text { this was done once } \\
\text { a day for } 2 \text { minutes, } \\
\text { was carried out for } 7 \\
\text { days, the control } \\
\text { group was not } \\
\text { treated. }\end{array}$ & $\begin{array}{l}\text { There was a decrease in the intervention } \\
\text { group with a value of } 3.00 \text { and in the control } \\
\text { group the result was } 0.36 \text {. The results of the } \\
\text { Independent T-test statistical test } \rho=0.010 \\
<\alpha=0.05 \text {. HO is rejected, which means that } \\
\text { acupressure has an effect on reducing nausea } \\
\text { and vomiting. Acupressure that is done } \\
\text { regularly can reduce complaints of nausea } \\
\text { and vomiting and prevent complications in } \\
\text { pregnant women. } \\
\text { DOI: } \\
\text { https://doi.org/10.36456/embrio.v11i2.2046 }\end{array}$ \\
\hline 4. & $\begin{array}{l}\text { (Mariza \& } \\
\text { Ayuningtias, } \\
\text { 2019) } \\
\text { Index: S4 }\end{array}$ & $\begin{array}{l}\text { Application of } \\
\text { acupressure at } \\
\text { point P6 to } \\
\text { emesis } \\
\text { gravidarum in } \\
\text { 1st trimester } \\
\text { pregnant women }\end{array}$ & $\begin{array}{l}\text { Quantitative } \\
\text { research } \\
\text { type, Quasi } \\
\text { experimental } \\
30 \quad \text { mothers } \\
\text { pregnant, TM } \\
1 \text {, gestational } \\
\text { age } 10-16 \\
\text { weeks, age } \\
20-40 \text { years }\end{array}$ & $\begin{array}{l}\text { Do massage on the } \\
\text { location of } 3 \text { fingers } \\
\text { above the wrist and } \\
\text { circular, done for } 7 \\
\text { minutes in the } \\
\text { morning. This } \\
\text { technique is carried } \\
\text { out } 4 \text { days. The } \\
\text { evaluation used } \\
\text { questionnaire the } \\
\text { Rhodes index on } \\
\text { day } 5 \text { in the morning. }\end{array}$ & $\begin{array}{l}\text { The results obtained } p \text { value }=0.000 \text {, which } \\
\text { means that there is an effect of giving } \\
\text { acupressure techniques at point P6 } \\
\text { ongravidarum emesis } \\
\text { DOI: } \text { https://doi.org/10.33024/hjk.v13i3.1363 }\end{array}$ \\
\hline 5. & $\begin{array}{l}\text { (Dewi } \quad \& \\
\text { Saidah } \\
\text { 2020) } \\
\text { Index: S3 }\end{array}$ & $\begin{array}{l}\text { Effect Of } \\
\text { Complementary } \\
\text { Acupressure } \\
\text { Therapy On } \\
\text { Emesis } \\
\text { Gravidarum In } \\
\text { Pregnant } \\
\text { Women First } \\
\text { Trimester }\end{array}$ & $\begin{array}{l}\text { Quasy } \\
\text { Experiment } \\
\text { Design } \\
16 \text { trimester } 1 \\
\text { pregnant } \\
\text { women }\end{array}$ & $\begin{array}{l}\text { This research was } \\
\text { conducted by giving } \\
\text { a pre-test before } \\
\text { being given } \\
\text { treatment, after } \\
\text { being processed, } \\
\text { then given a } \\
\text { posttest. } \\
\text { intervention given } \\
\text { was acupressure } \\
\text { therapy at point P6. }\end{array}$ & $\begin{array}{l}\text { In the Wilcoxon test, there was a significant } \\
\text { result, namely } p \text { value } 0.002(p<0.05) \text {, which } \\
\text { means that there was a significant effect } \\
\text { related to acupressure point P6 therapy in } \\
\text { pregnant women who experienced emesis } \\
\text { gravidarum. } \\
\text { DOI: https://doi.org/10.30994/sjik.v9i2.413 }\end{array}$ \\
\hline 6. & $\begin{array}{l}\text { (Tanjung et al., } \\
\text { 2020) } \\
\text { Index: S4 }\end{array}$ & $\begin{array}{lr}\text { Effect } & \text { of } \\
\text { Acupressure } & \text { at } \\
\text { Pericardium } & 6 \\
\text { Point } & \text { on } \\
\text { Intensity of } \\
\text { Nausea and } \\
\text { Vomiting in First } \\
\text { Trimester } \\
\text { Pregnant } \\
\text { Women }\end{array}$ & $\begin{array}{l}\text { Quasi } \\
\text { experiment } \\
\text { One Group } \\
\text { Pretest - } \\
\text { Posttest Only } \\
\text { Design } \\
20 \text { pregnant } \\
\text { women with } \\
\text { 1st trimester }\end{array}$ & $\begin{array}{l}\text { Assessing the } \\
\text { intensity of nausea } \\
\text { and vomiting using } \\
\text { Pregnancy-Unique } \\
\text { Quantification of } \\
\text { Emesis and Nausea } \\
\text { (PUQE) } \\
\text { Researchers } \\
\text { performed } \\
\text { acupressure } \\
\text { pericardium } 6 \text { on }\end{array}$ & $\begin{array}{l}\text { There is an effect of acupressure action at the } \\
\text { pericardium point } 6 \text { (P6) on the intensity of } \\
\text { nausea and vomiting of pregnant women in } \\
\text { the first trimester with a } p \text { value of } 0.000 \text { ( } p \\
<0.05 \text { ). } \\
\text { E.ISSN.2614-6061 } \\
\text { P.ISSN.2527-4295 }\end{array}$ \\
\hline
\end{tabular}




\begin{tabular}{|c|c|c|c|c|c|}
\hline & & & & $\begin{array}{l}\text { pregnant women } \\
\text { who experienced } \\
\text { nausea and } \\
\text { vomiting. This } \\
\text { intervention was } \\
\text { carried out within } 30 \\
\text { seconds to } 2 \\
\text { minutes in the } \\
\text { morning and evening } \\
\text { for } 5 \text { days. }\end{array}$ & \\
\hline 7. & $\begin{array}{l}\text { (Devi et al., } \\
\text { 2020) } \\
\text { Index: Q4 }\end{array}$ & $\begin{array}{l}\text { Effectiveness of } \\
\text { P6 Acupressure } \\
\text { on Reduction of } \\
\text { Nausea, } \\
\text { Vomiting \& } \\
\text { Retching among } \\
\text { Antenatal } \\
\text { Women } \\
\text { attending } \\
\text { Antenatal Clinic } \\
\text { at District } \\
\text { Hospitals of } \\
\text { Sikkim }\end{array}$ & $\begin{array}{l}\text { Randomized } \\
\text { Clinical Trial } \\
80 \text { pregnant } \\
\text { women, } \\
\text { gestational } \\
\text { age 8- } 12 \\
\text { weeks. }\end{array}$ & $\begin{array}{l}\text { The experimental } \\
\text { group applied } \\
\text { acupressure using a } \\
\text { wristband placed on } \\
\text { the wrist for } 24 \text { hours } \\
\text { for } 4 \text { days. If there } \\
\text { are side effects such } \\
\text { as redness, swelling, } \\
\text { and tenderness, the } \\
\text { patient is instructed } \\
\text { to remove the } \\
\text { acupressure bracelet } \\
\text { for } 15 \text { minutes. }\end{array}$ & $\begin{array}{l}\text { Nausea and vomiting as well as retching } \\
\text { scores in the experimental group showed a } \\
\text { significant reduction compared to the control } \\
\text { group }(p<0.001) \text {. Acupressure at point P6 has } \\
\text { been shown to be effective at reducing the } \\
\text { duration, discomfort, and frequency of } \\
\text { nausea, vomiting and retching. } \\
\text { DOI: } \\
\text { https://doi.org/10.24321/2455.9318.202005 }\end{array}$ \\
\hline 8. & $\begin{array}{l}\text { (Galeshi et al., } \\
\text { 2020) } \\
\text { Index: Q2 }\end{array}$ & $\begin{array}{l}\text { A comparison of } \\
\text { the effect of } \\
\text { pressure on the } \\
\text { KID21 (Youmen) } \\
\text { and P6 } \\
\text { (Neiguan) points } \\
\text { on the severity of } \\
\text { nausea and } \\
\text { vomiting of } \\
\text { pregnancy }\end{array}$ & $\begin{array}{l}\text { Randomized } \\
\text { single-blind } \\
\text { clinical trial } \\
82 \text { pregnant } \\
\text { women, ages } \\
18-35 \text { years. } \\
1 \text { st trimester } \\
\text { with } \\
\text { moderate to } \\
\text { severe NVP }\end{array}$ & $\begin{array}{l}82 \text { participants were } \\
\text { randomly assigned } \\
\text { to the pressure } \\
\text { groups KID21 and } \\
\text { P6. Researchers } \\
\text { applied pressure to } \\
\text { these two points for } \\
2 \text { minutes ( } 1 \text { minute } \\
\text { clockwise, } 1 \text { minute } \\
\text { counterclockwise) } \\
\text { every day for four } \\
\text { consecutive days. }\end{array}$ & $\begin{array}{l}\text { The severity of NVP in the } 82 \text { participating } \\
\text { pregnant women decreased in all groups ( } p \\
<0.001) \text {, and there was no significant } \\
\text { difference between the two groups in the } \\
\text { severity of NVP ( } p=0.68 \text { ). The reduction in } \\
\text { nausea was greater in the P6 group than in } \\
\text { the group. KID21, and the decrease in } \\
\text { vomiting was greater in the KID21 group than } \\
\text { in the P6 group. } \\
\text { DOI: } \\
\text { https://doi.org/10.1515/icim-2019-0035 }\end{array}$ \\
\hline 9. & $\begin{array}{l}\text { (Meiri \& Kibas, } \\
\text { 2018) } \\
\text { Index: S4 }\end{array}$ & $\begin{array}{lr}\text { Effect } & \text { of } \\
\text { Acupressure at } \\
\text { Nei Guan, Zu } \\
\text { Sanli and } \\
\text { Gongsun Points } \\
\text { on Reducing } \\
\text { Nausea and } \\
\text { Vomiting in First } \\
\text { Trimester } \\
\text { Pregnant } \\
\text { Women in Pmb } \\
\text { Afah Fahmi } \\
\text { A.Md. Keb } \\
\text { Surabaya }\end{array}$ & $\begin{array}{l}\text { Quasi } \\
\text { experiment, } \\
\text { One group } \\
\text { pretest - } \\
\text { Posttest } \\
\text { design } \\
15 \text { trimester } 1 \\
\text { pregnant } \\
\text { women }\end{array}$ & $\begin{array}{l}\text { Conducted a pre test } \\
\text { so that researchers } \\
\text { know that there is a } \\
\text { decrease in nausea } \\
\text { and vomiting after } \\
\text { being given } \\
\text { acupressure } \\
\text { techniques for } 9 \\
\text { days at points Nei } \\
\text { Guan, Zu San Li and } \\
\text { Gong Sun. }\end{array}$ & $\begin{array}{l}\text { The results showed that there was a decrease } \\
\text { in nausea and vomiting in pregnant women in } \\
\text { the } 1 \text { st trimester. The Wilcoxon test } p \text {-value } \\
\text { was } 0.000<a(0.05) \text {. } \\
\text { DOI: https://doi.org/10.35842/mr.v13i3.175 }\end{array}$ \\
\hline
\end{tabular}

\section{DISCUSSION}

Based on a study entitled The Effect of Acupressure on the Severity of Nausea, Vomiting, and Retching in Pregnant Women conducted by Tara et al, (2020) using a sample, women with first and single pregnancies as many as 90 participants. Researchers divided into 3 groups, namely the PC6 acupressure group, the sham acupressure performed in Waiguan and the vitamin B6 treatment group. All respondents have a gestational age of less than 12 weeks. The exclusion criteria in this study were respondents who had gastrointestinal problems, urinary tract infections, and hyperemesis gravidarum. The intervention carried out in the PC6 acupressure group, namely the researchers 
applied pressure to thepoint Neiguan or PC6 4 times a day with the time in the morning after waking up, afternoon, evening, and night before going to sleep for 10 minutes. This pressure is applied with the greatest possible endurance with constant pressure. There were significant changes on the fifth day in terms of frequency of vomiting, difficulty vomiting, amount of vomiting, duration of nausea, difficulty of nausea, frequency of nausea, and frequency of retching ( $p$ $<0.001$ for each outcome). The overall results of the study indicated that the PC6 pressure intervention was significantly more effective than the drug therapy intervention. This is consistent with a study that the frequency of vomiting, nausea, and vomiting, as well as discomfort caused by nausea and vomiting was significantly lower in the PC6 acupoint pressure treatment group than in the control group undergoing drug therapy. Another study conducted in Turkey showed that in subjects undergoing PC6 stress, there was a decrease in the severity of nausea, the frequency of vomiting, and feelings of discomfort after nausea.

Whereas in Handayani and Khairiyatul's research, (2019) with respondents 22 pregnant women who have a pregnancy in the first to second trimesters. Respondents were given acupressure treatment at the point of the pericardium 6 which is located on 3 fingers above the wrist. The pressure is applied using the tip of the thumb. Initial pressing is done gently, then continued gradually using the force of the added pressure until you feel a light sensation, but do not cause pain. The acupressure is done once a day for 2 minutes. Intervention on these respondents was carried out for 7 days. Based on the results of the paired T-test, there was a significant difference before acupressure therapy was carried out and after acupressure therapy was carried out with $\rho<a$ so that $\mathrm{H} 0$ was rejected, which means that acupressure therapy had an effective effect on reducing complaints of nausea and vomiting in pregnant women.

Similar to Mariza and Ayuningtias' research, (2019) showed a result, namely that there was an effect of giving acupressure therapy at point $P 6$ on emesis gravidarum with a statistical test value of $p$ value $=0.000$. The acupressure was given to respondents with the criteria that pregnant women were between 20-40 years old, had age of gestational 10 to 16 weeks and experienced moderate complaints of nausea and vomiting based on the INVR value of 9-16. Respondents were given acupressure treatment at point P6 for 7 minutes in the morning. This technique is done by the respondents themselves for 4 consecutive days.

These results are also in accordance with the research of Tanjung et al. (2020) obtained a value of $p 0,000$ and it can be concluded that acupressure carried out in pericardium 6 has a major effect on the intensity of nausea and vomiting of pregnant women in the 1st trimester. acupressure at P6 with a time of 1 minute or 30 seconds to 2 minutes, done in the morning and evening. The intervention was carried out for 5 days. Respondents performed acupressure therapy by sitting or lying down in a comfortable position. If pregnant women feel relaxed or comfortable, then pregnant women can repeat the procedure. The characteristics of this study, most of the respondents were in the age group 26-35 years with the first trimester and experienced nausea and vomiting.

In Dewi and Saidah's research, (2020) which had pregnant women respondents before the acupressure intervention there were 3 people who experienced mild nausea and vomiting, 10 people experienced moderate nausea and vomiting, and 3 other pregnant women experienced severe nausea and vomiting. The pregnant woman was then given acupressure therapy at point P6. After being given the therapy, it was found that 10 pregnant women (62.5\%) experienced mild changes in nausea and vomiting, while 6 other pregnant women experienced moderate nausea and vomiting with a result of $37.5 \%$. So, the researchers concluded that acupressure therapy at point P6 is a complementary therapy that can reduce complaints of nausea, vomiting or emesis gravidarum in first trimester pregnant women.

However, based on a study entitled the effect of P6 acupressure on nausea and vomiting of pregnancy conducted by Mobarakabadi et al, (2020) using a sample of pregnant women with gestational age criteria under 20 weeks, and consisting of 75 respondents. Respondents had complaints of mild to moderate nausea and / or vomiting which had been measured using a Likert scale before starting the intervention. This study had exclusion criteria, including hyperemesis gravidarum, pregnant women who needed hydration therapy or antiemetic drugs, and those who had a history of accidents or trauma. In the acupressure group the intervention carried out was applying permanent pressure to point P6 using bracelets Sea-Band on both wrists. The intervention was carried out for 3 days, except when the participant went to the bathroom, then the bracelet was removed first. For the placebo group they used the wristbands in the same method as the acupressure group but without the presence of a push button on the wristbands. There were differences in the mean value of nausea with respect to the frequency, duration, and severity after the interventions with a $P$ value $<0.001$. The investigators also found a significant difference in the frequency of vomiting with a result of $P=$ 0.02. This means that P6 acupressure using Sea-Band can reduce the frequency and severity of nausea and the frequency of vomiting. Whereas in the Tukey Test, the acupressure and placebo groups did not differ significantly from each other in this respect $(P=0.61)$. These results are consistent with previous studies that the use of Sea-Bands at point P6 can reduce the severity of nausea and vomiting. Another similar study also found that the significant difference between the acupressure and placebo groups was due to first, it could be argued that the women who wore the bracelet 
believed the band would reduce their nausea and vomiting, indicating a placebo effect. Second, the bracelet used in the placebo group stimulated the $\mathrm{P} 6$ point even without a push button.

This is in line with research by Devi et al. (2020) who argued that there was a significant reduction in the mean score for nausea, vomiting and retching and the total score after applying acupressure wristbands on P6 in antenatal women. This has been proven in 40 pregnant women in the experimental group with complaints of mild nausea, with or without vomiting and retching with gestational age 10 to 12 weeks. Participants in the experimental group received acupressure wristbands worn at the P6 point neiguan for 4 days in 24 hours unless the pregnant women were about to shower, they could take them off.

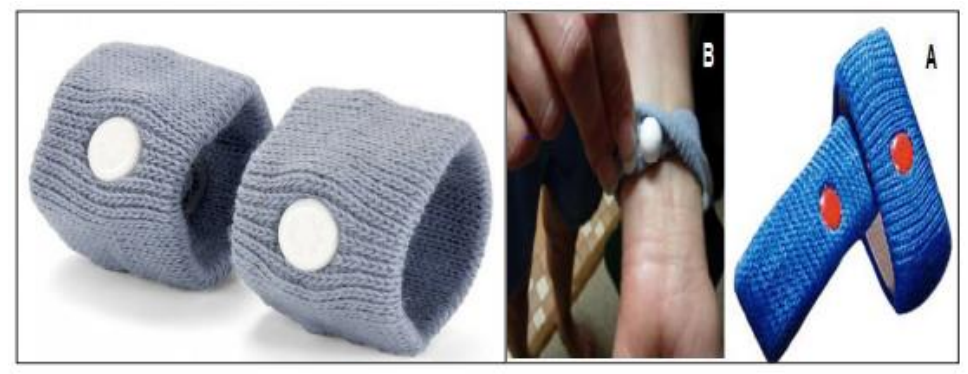

Figure 2. Acupressure wristband (Source: Devi et al, 2020)

An acupressure wristband is a product used at points neiguan in acupressure. It consists of an elastic band that is joined by plastic buttons to apply pressure to the skin at specific acupoints. If there are side effects such as redness, swelling, and tenderness or paranesthesia, the patient is instructed to remove the acupressure bracelet for 15 minutes by recording the time and cause in a diary. The results in this study after intervening with acupressure therapy using a bracelet at point P6, an average of nausea $(6.35 \pm<0>3.77)$, vomiting $(4.42 \pm 3.85)$ and score retching obtained $(2.6 \pm$ $2,24)$. This indicates that the mean post test score is lower than the mean pre-test score which was found to be statistically significant than the control group.

In addition to the P6 acupressure point, complaints of nausea and vomiting in pregnant women can be done at other points. There is a study entitled A comparison of the effect of pressure on the KID21 (Youmen) and P6 (Neiguan) points on the severity of nausea and vomiting of pregnancy, researchers conducted acupressure therapy at the KID21 point or yumumen and P6 point or neiguan in pregnant women with ages 18-35 years are in the first trimester and have a singleton pregnancy. The pregnant woman had moderate to severe NVP complaints. Researchers divided into 2 groups, namely the KID21 group of 42 participants and the P6 group of 40 participants who were followed until the end of the study. Both groups received $80 \mathrm{mg}$ of vitamin B6 daily (2 tablets $40 \mathrm{mg}$ every 12 hours) prior to the acupressure intervention. This is because the researcher did not prevent one group from getting the minimum treatment out of respect for ethics. Researchers performed acupressure interventions in a supine position between 17.00 and 19.00 in pregnant women. Furthermore, a trained researcher gently placed his thumb on the KID21 point in the first group and at the P6 point in the second group and gradually applied painless pressure. If there is pain, the researcher stops applying pressure until there is no pain, then continues the pressure. The pressure is applied for 2 minutes at the point pressure KID21 or P6, which is 1 minute clockwise and 1 minute counter clockwise. Then, the application of pressure is stopped and the point is massaged for another 2 minutes just for meridian stimulation. This process continues for up to 20 minutes. Pressure was applied by the researcher for 4 consecutive days, each day for 20 minutes. The results showed that there was a decrease in the severity of nausea in both groups for 4 days, but there was no significant difference between the two groups $(F=1.54, d f=1, p=0.21)$ although the decrease in nausea was greater in the $P 6$ group than in the KID group. The severity of vomiting also decreased in both groups during these 4 days, but there was no significant difference between the two groups $(F=1.19$, $d f=1, p=0.27$ ) although the decrease in vomiting was greater in the KID21 group than in the P6 group. This study shows that pressure at the P6 and KID21 points can reduce the severity of NVP, but neither point has an advantage over the others in reducing this complaint (Galeshi et al, 2020).

Whereas in the research of Meiri and Kibas, (2018) the respondents were 15 pregnant women in the first trimester. The researcher gave an intervention, namely giving acupressure for 9 days at the Nei Guan or P6 point, Zu San $\mathrm{Li}$, and the Gong Sun point to the respondent. There are results, namely $(P<0.05)$, which means that there is an effect of acupressure therapy to reduce complaints of nausea and vomiting of pregnant women because these points 
can produce a stimulation that causes the hormone cortisol to come out, so that it can increase a metabolism in the body and complaints of nausea. vomiting in pregnant women that you feel can be reduced.

\section{CONCLUSION}

Based on several journal articles that have been reviewed, it can be concluded that there is an effect of acupressure therapy at the point neiguan or P6, the KID point21. (Youmen), St 36 (Zu San Li), and point Sp 3 (Gong Sun) to reduce complaints of nausea and vomiting of pregnant women. This therapy is effectively given by applying pressure using the tip of the thumb. The intensity of the initial pressing is done gently, then the strength of the pressure is increased gradually but does not cause pain in the patient. Emphasis is given by turning clockwise. The duration of time for giving P6 acupressure therapy using the thumb is carried out 2-10 minutes 4 times a day, namely in the morning after waking up, noon, evening, and night before going to sleep in 3-7 days. This intervention can be done in a sitting or lying position in a position that is comfortable for the patient. While acupressure therapy using an acupressure bracelet or wristband is effective for pregnant women with a duration of 24 hours for 3-4 days, except for bathing, the bracelet must be removed. If there are side effects such as redness, swelling, and tenderness or paranesthesia when using the acupressure bracelet, the patient can remove the acupressure bracelet for 15 minutes. Based on the results of a review of several studies, acupressure therapy is not indicated for pregnant women who have gastrointestinal problems, urinary tract infections, and have a history of accidents or trauma. But acupressure therapy is more effective for pregnant women who have mild to moderate complaints of nausea and vomiting, from the first to the early second trimester, namely 6-19 weeks of pregnancy, and the mother's age is $18-40$ years.

The suggestions for preparing the next literature review include searching for better articles in the last 5 years, which aim that the articles to be reviewed are the latest and most recent articles, search for journal articles is carried out on a varied database so that the articles obtained are more numerous and homogeneous, and more pay attention to the inclusion and exclusion criteria in the search for articles so that the implementation of the next literature review is more focused.

\section{ACKNOWLEDGEMENT}

Thank you to all who have participated and helped in the process of compiling this literature review. This literature review is prepared without conflict in the writing.

\section{REFERENCES}

Devi, Lepcha, \& Das. (2020). Effectiveness of P6 Acupressure on Reduction of Nausea, Vomiting \& Retching among Antenatal Women attending Antenatal Clinic at District Hospitals of Sikkim. International Journal of Nursing \& Midwifery Research, 07(01), 24-30. https://doi.org/10.24321/2455.9318.202005

Dewi, R. K., \& Saidah, H. (2020). Effect Of Complementary Acupressure Therapy On Emesis Gravidarum In Pregnant Women Trimester I. STRADA Jurnal IImiah Kesehatan, 9(2), 1065-1071. https://doi.org/10.30994/sjik.v9i2.413

Dewi, W. S., \& Safitri, E. Y. (2018). Pengaruh Aromaterapi Lemon terhadap Emesis Gravidarum di Praktik Mandiri Bidan Wanti Mardiwati. Jurnal IImiah Kesehatan, 17(3), 4-8. https://doi.org/10.33221/jikes.v17i3.173

Dhilon, D. A., \& Azni, R. (2018). Pengaruh Pemberian Terapi Aroma Jeruk Terhadap Intensitas Rasa Mual dan Muntah pada Ibu Hamil di Wilayah Kerja Puskesmas Harapan Raya. Jurnal Doppler Universitas Pahlawan Tuanku Tambusai, 2(1), 58-65.

Faridah, Ponda, \& Pertiwi. (2020). PENGARUH MINUMAN JAHE TERHADAP PENURUNAN FREKUENSI EMESIS GRAVIDARUM PADA IBU HAMIL TRIMESTER I DI WILAYAH PUSKESMAS LUBUK BUAYA PADANG. IImiah Kesehatan Ar-Rum Salatiga, 4(1), 23-32. https://doi.org/https://doi.org/10.36409/jika.v4i1.57

Fatwa Tasya T. (2020). PENGARUH REBUSAN JAHE TERHADAP KELUHAN MUAL MUNTAH IBU HAMIL. Jurnal Medika Hutama, 2(May), 48-59. Retrieved from https://www.opensocietyfoundations.org/explainers/what-openaccess?utm_source=facebook.com\&utm_medium=referral\&utm_campaign=osffbpg

Galeshi, M., Ghanbarpour, A., Naeimi Rad, M., \& Asghari, S. (2020). A comparison of the effect of pressure on the KID21 (Youmen) and P6 (Neiguan) points on the severity of nausea and vomiting of pregnancy. Journal of Complementary and Integrative Medicine, 17(2), 1-9. https://doi.org/10.1515/jcim-2019-0035

Handayani, N., \& Khairiyatul, R. K. A. (2019). Pengaruh Akupresur Terhadap Penurunan Mual Dan Muntah Pada Ibu Hamil Di Praktek Mandiri Bidan Sidoarjo. Embrio, 11(2), 102-109. https://doi.org/10.36456/embrio.vol11.no2.a2046

Henuk, D. M. S., \& Pattypeilohy, A. (2019). Chmk midwifery scientific journal volume 2, nomor 2 april 2019 pengaruh minuman sari jahe dalam mengurangi emesis gravidarum pada ibu hamil di puskesmas alak. Journal of Chemical Information and Modeling, 2(April), 39-44.

Maheswara, Wahyuni, Istiqomah, \& Kustiyati. (2020). Literature Review: Terapi Komplementer Akupresur pada Titik Perikardium 6 
dalam Mengatasi Mual dan Muntah pada Kehamilan. Urecol, 3(1), 40-50.

Mariza, A., \& Ayuningtias, L. (2019). Penerapan akupresur pada titik P6 terhadap emesis gravidarum pada ibu hamil trimester 1. Holistik Jurnal Kesehatan, 13(3), 218-224. https://doi.org/10.33024/hjk.v13i3.1363

Meiri, E., \& Kibas, N. (2018). Pengaruh Akupressure Pada Titik Nei Guan, Zu Sanli, dan Gongsun terhadap Pengurangan Mual Muntah Pada Ibu Hamil Trimester 1. Jurnal Medika Respati, 13(3), 7-12. https://doi.org/https://doi.org/10.35842/mr.v13i3.175

Mobarakabadi, S. S., Shahbazzadegan, S., \& Ozgoli, G. (2020). The effect of P6 acupressure on nausea and vomiting of pregnancy: A randomized, single-blind, placebo-controlled trial. Advances in Integrative Medicine, 7(2), 67-72. https://doi.org/10.1016/j.aimed.2019.07.002

Ramadhani, I. P., \& Ayudia, F. (2019). Pengaruh Pemberian Minuman Jahe (Zingiber Officinale Var. Rubrum) Terhadap Penurunan Emesis Gravidarum Trimester Pertama. Jik- Jurnal IImu Kesehatan, 3(2), 97. https://doi.org/10.33757/jik.v3i2.231

Renityas, N. N. (2019). Pengaruh Titik Nei Guan (P6) Terhadap Pengurangan Keluhan Morning Sickness pada Ibu Hamil Trimester I di Puskesmas Sanwetan Blitar. Jurnal Kesehatan, 3(1), 46-49.

Soa, U. O. M., Amelia, R., \& Octaviani, D. A. (2018). Perbandingan Efektivitas Pemberian Rebusan Jahe Merah Dan Daun Mint Dengan Jeruk Nipis Dan Madu Terhadap Mual Muntah Pada Ibu Hamil Trimester I Di Puskesmas Waepana, Ngada, Ntt. Jurnal Kebidanan, 8(2), 157. https://doi.org/10.31983/jkb.v8i2.3745

Sulistiarini, U., Widyawati, M. N., \& Rahayu, D. L. (2018). Studi Literatur: Acupressure Pericardium Dan Aromatherapy Citrus Untuk Mengurangi Mual Muntah Ibu Hamil. Jurnal Kebidanan, 8(2), 146. https://doi.org/10.31983/jkb.v8i2.3744

Suryaningrum, K. C., Titisari, I., \& Mediawati, M. (2018). Hubungan Antara Status Gravida dan Usia Ibu Dengan Kejadian Emesis Gravidarum. Jurnal IImu Kesehatan, 7(2), 12-20.

Tanjung, W. W., Wari, Y., \& Antoni, A. (2020). Pengaruh Akupresur Pada Titik Perikardium 6 Terhadap Intensitas Mual Muntah Pada Ibu Hamil Trimester I. Jurnal Education and Development, 8(4), 265-270. https://doi.org/https://doi.org/10.37081/ed.v8i4.2160

Tara, F., Bahrami-Taghanaki, H., Amini Ghalandarabad, M., Zand-Kargar, Z., Azizi, H., Esmaily, H., \& Azizi, H. (2020). The Effect of Acupressure on the Severity of Nausea, Vomiting, and Retching in Pregnant Women: A Randomized Controlled Trial. Complementary Medicine Research, 27(4), 252-259. https://doi.org/10.1159/000505637

Wahyuningsih S. (2019). Buku Ajar Keperawatan Maternitas (A. Maisyaroh \& R. Kholis, Eds.). Bondowoso: CV KHD Production.

Widyastuti, D. E., Rumiyati, E., \& Widyastutik, D. (2019). Terapi Komplementer Akupresur Untuk Mengatasi Emesis Gravidarum Pada Ibu Hamil Trimester I Tahun 2018. Jurnal Kebidanan Indonesia, 10(1), 96. https://doi.org/10.36419/jkebin.v10i1.248

World Health Organization. (2014). Emesis Gravidarum.

Wulandari, D. A., Kustriyanti, D., \& Aisyah, R. (2019). Minuman Jahe Hangat Untuk Mengurangi Emesis Gravidarum Pada Ibu Hamil Di Puskesmas Nalumsari Jepara. Jurnal SMART Kebidanan, 6(1), 42. https://doi.org/10.34310/sjkb.v6i1.246 